\title{
Place reference in story beginnings: A cross-linguistic study of narrative and interactional affordances
}

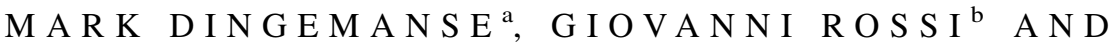 \\ $S$ I M E N F LOY D ${ }^{\mathrm{c}}$ \\ ${ }^{a}$ Max Planck Institute for Psycholinguistics \\ ${ }^{b}$ University of Helsinki \\ ${ }^{c}$ Radboud University
}

\section{A B S T R A C T}

\begin{abstract}
People often begin stories in conversation by referring to person, time, and place. We study story beginnings in three societies and find place reference is recurrently used to (i) set the stage, foreshadowing the type of story and the kind of response due, and to (ii) make the story cohere, anchoring elements of the developing story. Recipients orient to these interactional affordances of place reference by responding in ways that attend to the relevance of place for the story and by requesting clarification when references are incongruent or noticeably absent. The findings are based on 108 story beginnings in three unrelated languages: Cha'palaa, a Barbacoan language of Ecuador; Northern Italian, a Romance language of Italy; and Siwu, a Kwa language of Ghana. The commonalities suggest we have identified generic affordances of place reference, and that storytelling in conversation offers a robust sequential environment for systematic comparative research. (Storytelling, place, narrative, conversation analysis, interactional linguistics)*
\end{abstract}

\section{N T R O D U C T I O N}

When we think about references to places like in the supermarket, at home, in London, we often focus on their use in locating things and going to places. But place references are not just neutral locators: they are as intersubjective, perspectival, and inferentially rich as any other device for reference in conversation. Here we examine the use of place reference in everyday social interaction, focusing on a sequential environment that is common and comparable across languages: stories. We study the interactional functions and linguistic formatting of place reference in story beginnings in three unrelated languages: Cha'palaa, a Barbacoan language of Ecuador; Northern Italian, a Romance language spoken in Italy; and Siwu, a Kwa language of Ghana.

We define a place reference as a possible answer to a where-question. Any place can be referred to in many alternative ways, from place names to deictic expressions, and from pointing gestures to topological descriptions (Levinson 2003). Also, place 
references can be logically contained in other place references, so they have a recursive, fractal nature (Enfield 2013). The diversity of alternative reference forms provides people with resources for social action: choosing one possible formulation over another is a way of doing interactional work. In an early study on 'locational formulation', Schegloff (1972) pointed out how alternative formulations can be used for actions beyond reference, for instance, to evoke a stage in life, to demonstrate one's knowledge of a city, or to foreground an activity. The formulation, recognition, and resolution of place reference relies heavily on conversational context and shared cultural knowledge (Kuipers 1984; Basso 1984).

Work in descriptive and typological linguistics has documented the range of linguistic resources for referring to place both within and across different languages (Bloom, Peterson, Nadel, \& Garrett 1996; Levinson \& Wilkins 2006). The interactional use of these resources, however, has received less systematic attention in cross-linguistic research. Are there functions that place references consistently fulfil across unrelated languages? And are comparable forms used for these functions? Such questions can only be answered by a systematic comparative study of place reference in conversation. Stories provide a good context to carry out such a study, as they are found across cultures. We focus on personal stories told in everyday conversation - so-called 'small stories' (Bamberg \& Georgakopoulou 2008) - and build on insights from conversation analysis, narrative research, and linguistic typology to understand the interactional affordances of place reference in story beginnings.

\section{A N E X A M P L E}

Let us set the stage with an excerpt from the BBC comedy quiz show QI. Comedians Jimmy Carr and Sue Perkins are talking with host Stephen Fry about funerals. After some talk about picking coffin designs from a brochure (following a quiz question about figurative coffins made in Ghana), Jimmy starts a story at line $5 .{ }^{1}$

(1) 'I was once in a graveyard', QI Series 7, Episode 13 (English)

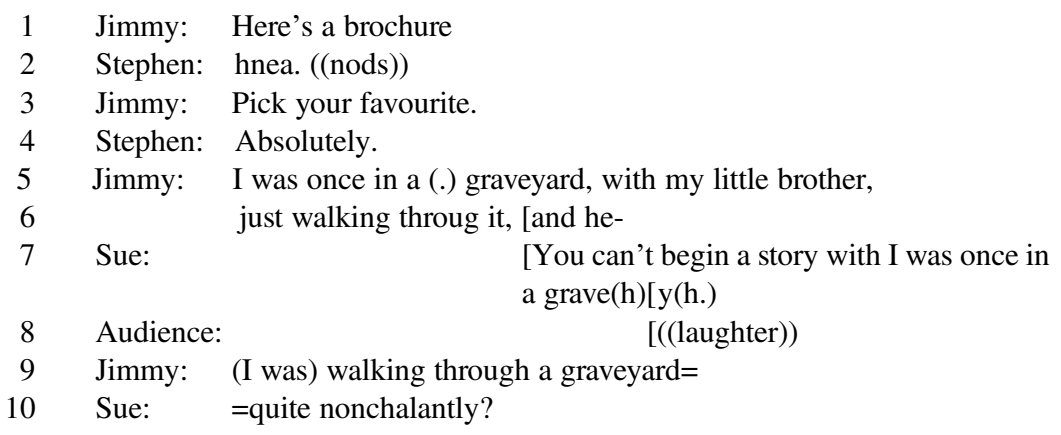


11 Jimmy: (h)yeah(h), (.) I, you know the kind of old gravestones with the, (.) with the curly bits at the [top ((gestural depiction of gravestone))

12 Stephen: [yes:

13 Jimmy: and he thought that that's where chefs were buried.

14 Audience: ((laug[hter))

15 Stephen: [个oo:h.

At line 5, Jimmy says, I was once in a graveyard, with my little brother, just walking through it. In overlap with the continuation of his turn, Sue comes in, You can't begin a story with 'I was once in a grave(h)y(h.)'. Three things are notable about this interruption. First, Sue identifies what Jimmy has done at line 5 as 'beginning a story'. So story beginnings are recognised as a relevant practice by participants in interaction, and there must be features of Jimmy's turn-so-far that enable its identification as an instance of one such beginning. Second, Sue's interruption is a statement about how one cannot begin stories. This implies a normative understanding of how one SHOULD begin stories. Third, Sue singles out the place reference: when she quotes Jimmy's story beginning, she reproduces graveyard infused with laughter particles: grave( $h) y(h$.), eliciting laughter from the audience in return.

When Jimmy continues, Sue adds more detail on her reason for singling out this place reference: quite nonchalantly? (line 10), pointing to an incongruity of setting (graveyard) and activity (walking with your little brother). This brings to light the inferentially rich nature of place reference. A given setting evokes certain relevant activities and makes others unexpected or marked. So listeners inspect place references in story beginnings for the kind of story they project, and may hold tellers accountable for apparent incongruities.

Jimmy acknowledges Sue's question with a laughter-infused confirmation (line 11) and then finishes the story with a punchline, which relates to the visual similarity of certain old gravestones to chefs' hats. Following this punchline, the audience laughs, and host Stephen Fry produces an appreciative interjection $\uparrow o o: h$, both responses signifying a recognition that the story has now reached its conclusion. The responses also show that one can perfectly well begin a story with $I$ was once in a graveyard, for instance, if the punchline relies on this setting. In sum, story beginnings project something about endings, and listeners inspect beginnings for cues about when the story will end, when a response might be due, and what sort of response is relevant (Jefferson 1978; Sacks 1992).

We see in this example that place references occur in story beginnings; that listeners orient to what place references evoke, drawing inferences from them and inspecting them for congruity with other elements of the story; and that place references in this context can foreshadow and support the point of a story. While there seems to be nothing artificial about the story in extract (1), it is told by a comedian during a televised panel quiz in Britain, so we might wonder about the broader validity of these observations. In what follows, we examine place reference in story beginnings 
in informal everyday conversations in three unrelated languages. Our aim is twofold: (i) observe and explain the interactional and narrative affordances of place reference in stories told in conversation, and (ii) use cross-linguistic data to determine to what extent this is a general or a culturally specific phenomenon.

\section{STORIES IN CONVERSATION}

A prerequisite for the systematic comparative study of any conversational phenomenon is to identify a comparable context in which it occurs across different languages. This principle - by now established in comparative conversation-analytic research (Zimmerman 1999; Stivers et al. 2009; Dingemanse et al. 2015) and known as the natural or sequential control method (Dingemanse \& Floyd 2014) ensures a controlled environment for comparison across languages, cultures, or other relevant human differences. In this study, we focus on the context of stories and in particular on story beginnings.

Stories are important in human social life: they help us organise and share our identities, traditions, and social relationships, reflecting the full gamut of human experience (Bruner 1991). Stories are likely a universal human phenomenon (Barthes 1966) and offer a rich and robust context for cross-cultural comparison. We define a story in conversation as a multi-unit turn in which a speaker produces a temporally ordered report of some experience or event (Goodwin \& Heritage 1990:298-300). In the present study, we focus on stories that report the narrator's personal experiences in everyday social life, though we expect that our findings will apply to other types of stories as well.

Stories consist of multiple parts. Their internal structure makes story progression recognisable to listeners (Sacks 1992a:255) and aids comprehension and recall (Mandler \& Johnson 1977). Scholars of narrative have drawn up various models of story structure that include elements like 'setting', 'theme', 'complication', and 'resolution' (Propp 1928/1968; Labov \& Waletzky 1967; Rumelhart 1975; Thorndyke 1977). Despite slight differences in models of story structure, and possibly larger differences conditioned by genre and mode of storytelling, one element common to all of them is the setting (which Propp (1928/1968) called 'initial situation' and Labov \& Waletzky call 'orientation'), in which person, place, and time are specified. People are better at dealing with stories that have brief orienting introductions, as shown by various measures of comprehension and recall (Bransford \& Johnson 1972). Because story beginnings are found across cultures, and experimental research shows them to be important for comprehension and recall, they provide an excellent place to study the interactional work done by place reference.

\section{Story beginnings}

Much of the work on story structure reviewed above has stipulated or assumed the occurrence of story beginnings without giving much thought to their formulation or composition, let alone interaction and co-construction. This reflects a long-standing 
tradition of reifying stories as stand-alone texts that can essentially be studied in isolation. Here, in contrast, we are interested in how stories are launched in real-time interaction (Schegloff 1997; Georgakopoulou 2015). Telling a story in conversation poses a nontrivial set of interactional challenges (Jefferson 1978; Goodwin 1984; Sacks 1992a: [1966, 1968]; Sidnell 2010:174-96; Yasui 2011). A prospective storyteller has to convey at least (i) ТНАТ a story is coming up (to secure rights to produce a multi-unit turn), (ii) WHAT kind of story it will be (so that recipients can tell what kind of response is sought), and (iii) wHEN the story reaches completion (hence when the response is due and free turn-taking can resume). An important place to do at least some of the work towards these three goals is the story beginning (Sacks 1974). We can see this in Jimmy's story in extract (1): his first turn is recognised as a story beginning by the other participants; the story turns out to be a joke, as is recognised by the laughter of the participants; and the story beginning creates a context for the punch line of the joke, making the ending more recognisable.

Stories are sometimes launched with an explicit reference to the incipient storytelling activity: You wanna hear muh- eh my sister told me a story last night (Sacks 1974) or I'll tell you something (Jefferson 1978:248). Such 'prefaces' (Sacks) or 'pre-beginnings' (Jefferson) offer recipients a chance to solicit the full story (Sacks 1974:340). Although pre-beginnings that explicitly refer to the storytelling activity are easy to recognise, they are quite rare, at least in our corpora; more often, other features of turn design allow a turn to function as a story beginning (Ervin-Tripp \& Küntay 1997). Turns treated as story beginnings are often designedly incomplete: they cannot stand alone as a full report of an event, and as such make two things relevant: a response by a recipient, and the further telling of the story by the initiator. Such turns are floor seekers - practices 'that people use to have themselves, hopefully, selected as next speaker, where they are current speaker' (Sacks 1992a:665).

Turns treated as story beginnings often contain references to person, time, and/or place (Sacks 1986; Sidnell 2010:179; Rossano 2012:74-75). As Sacks noted in his analysis of a story told in conversation, 'Bullocks is a place. And the initial formulation of the story as a story about something happening at a place sets up a possibility that it is thereafter possible to mobilise a series of place-indexical terms (things like across the street, in front of the store, on the other side, etc.) which are thereafter read as terms applying to the initially named place, and which-if you watch the story you'll see - are used in pretty much every utterance in the story' (Sacks 1986:132). This use of place reference is a 'binding technique': an anchor to which subsequent referential formulations can tie back (Sacks 1986). Although our principal focus here is on the story beginning, we also keep track of how subsequent references to place contribute to coherence (Goodwin 1995).

\section{Data and methods}

The data for this study come from video corpora of naturally occurring conversations among consenting participants in three unrelated languages from three 
continents: Cha'palaa, a Barbacoan language of Ecuador; Northern Italian, a Romance language of Italy; and Siwu, a Kwa language spoken in Eastern Ghana. We focus on informal conversation, as this is the most robust baseline for comparative research into conversational structure (Dingemanse \& Floyd 2014). Conversations were transcribed and annotated in ELAN (Wittenburg, Brugman, Russel, Klassmann, \& Sloetjes 2006) with attention to verbal as well as visible behaviour. The resulting conversational corpora were sampled for the occurrence of stories.

In the data, we find a total of 108 personal stories. Within this collection we identify story beginnings using the next-turn proof procedure (Sacks, Schegloff, \& Jefferson 1974; Moerman \& Sacks 1988): story beginnings are turns treated as such by the participants in interaction. This retrospective, interactionally grounded definition recognises story beginnings as interactional achievements (Schegloff 1982) and makes it possible to investigate their design independently. Interactional evidence that a turn is treated as a story beginning may come in the form of an explicit ratification (as when Sue, in extract (1) above, identifies Jimmy's practice as 'beginning a story'), but more often, it is in the form of a go-ahead response or continuer by the story recipient, which ratifies the storytelling activity implicitly (see examples below).

Of the 108 stories in our collection, fifty-six — or a little over half-feature a place reference in the story beginning (Table 1). So, in contrast to a common assumption in narrative research, references to place are not part of story beginnings by default or by definition. Their presence in some cases and absence in others allows us to see their interactional affordances more clearly.

\section{N A R R A T IVE A N D IN TER ACT IO N A L A F F O R D A N C E S}

In Jimmy's graveyard story above, we saw that story-initial references to places may foreshadow a key point of a story and that listeners may inspect them for what they evoke and imply about the progression of the story. Here we trace the interactional uses of place reference in more detail. The analysis points to two central affordances: setting the stage and making the story cohere.

TABLE 1. Overview of the data.

\begin{tabular}{llcccc}
\hline \hline Language & Analyst & Interactions & Time sampled & Story beginnings & With place reference \\
\hline Cha'palaa & Floyd & 3 & $1 \mathrm{~h} 00$ & 34 & 16 \\
Italian & Rossi & 9 & $1 \mathrm{~h} 50$ & 36 & 16 \\
Siwu & Dingemanse & 4 & $1 \mathrm{~h} 20$ & 38 & 24 \\
& & 16 & $4 \mathrm{~h} 10$ & 108 & 56 \\
\hline \hline
\end{tabular}




\section{Setting the stage}

We start with another graveyard story, told in a different part of the world: Ghana. Three men, Odo, Koku, and Ruben, are taking a break from work and sharing stories about their experiences with dangerous animals. Koku has just finished telling a story about people eating python meat. (While eating snake meat is not uncommon in this society, most hunters avoid python, to which mythical powers are ascribed.) Odo's telling in extract (2) is a second story, a common way to engage with and respond to a first story (Sacks 1992a:764ff.). It relates to a dangerous encounter with a snake in the graveyard area.

(2) 'One day in the graveyard', Break_241548 (Siwu, Ghana) $)^{2}$

$1 \quad(3.2)$

2 Odo: iyì̀ ìw $\tilde{\varepsilon}$ abomè ní

day:INDEF one graveyard FP.urgent

'one day in the graveyard \{area\}!' ((areal point))

$3 \quad(0.5)$

$4 \quad$ Koku: $\uparrow \mathrm{M}: \uparrow(($ nods $))$

5 Odo: nto lo kelè sia, ìbere itì obe.

1s:PROG 1s go farm palm fruit it:ripe

'I was on the way to farm, the palmfruit was ripe'

$6 \quad(0.7)$

7 ngbó ó mìmini só kùgó ngbe.

how 3s:PST PLUR encircle self like this

((points up)) 'the way it coiled, like this' ((depicts a coiled snake))

8 Koku: j̀ sia.

$3 \mathrm{~s}$ be.located

'There it is.'

((body of story))

29 Odo: ne ló- tsuara ũ j̀dede j̀doè ne. TP 1s finally my hitting SCR:kill TP 'and I- finally my hitting killed it.'

$30 \quad(1.4)$

31 Koku: tsk (0.3) aye lalaà adé mmò lo.

INTJ snakes bad:ADJ they:be there FP.advice

'Tsk (0.3) bad snakes live there!'

32 Ruben: m-hm

'm-hm'

$33 \quad$ (0.3)

34 Koku: aye lalaà ló!

snakes bad:ADJ FP.advice

'bad snakes.' 
Odo begins with an indefinite time and a place reference supported by an areal pointing gesture: One day in the graveyard \{area\}. As an adjunct phrase mentioning a time and place but no person or predicate, Koku's turn is designedly incomplete, a tell-tale characteristic of story beginnings. The final particle $n i$ conveys a speaker's urgent demand for attention and serves as a claim of interestingness, helping to justify what may follow as tellable. A brief pause at the transition relevance place in line 3 provides an opportunity for a next speaker to come in and respond.

Koku's response at line 4-a vocal response token $\uparrow M$ : $\uparrow$ accompanied by a head nod-passes the floor back to Odo and functions as a go-ahead for the storytelling activity. The noticeably high pitch and loudness of this response token signals that it is doing something beyond its normal function as a continuer (Schegloff 1982): it appears to display an orientation to the urgency and excitement built into the story beginning through the $n i$ particle. The head nod is a token of affiliation, claiming 'I know what you mean' (Stivers 2008) and thereby confirming the noteworthiness of the place mentioned in the story preface.

What is it about this graveyard area that makes it a good place for a second story, given a first story about python meat? It is common local knowledge that the shady, moist graveyard area is a preferred habitat for snakes, and some of this knowledge is mobilised as the story continues. At line 5, Odo places himself in the area by explaining how he was on his way to farm in order to harvest palm fruit. To access their farmlands, many people from the village follow a forest trail that passes through the graveyard area (Figure 1). Combining speech and gesture, Odo describes how he encountered something coiled up in a tree (line 7), in reply to which Koku displays his involvement in the story: 'there it is' (line 8). In the

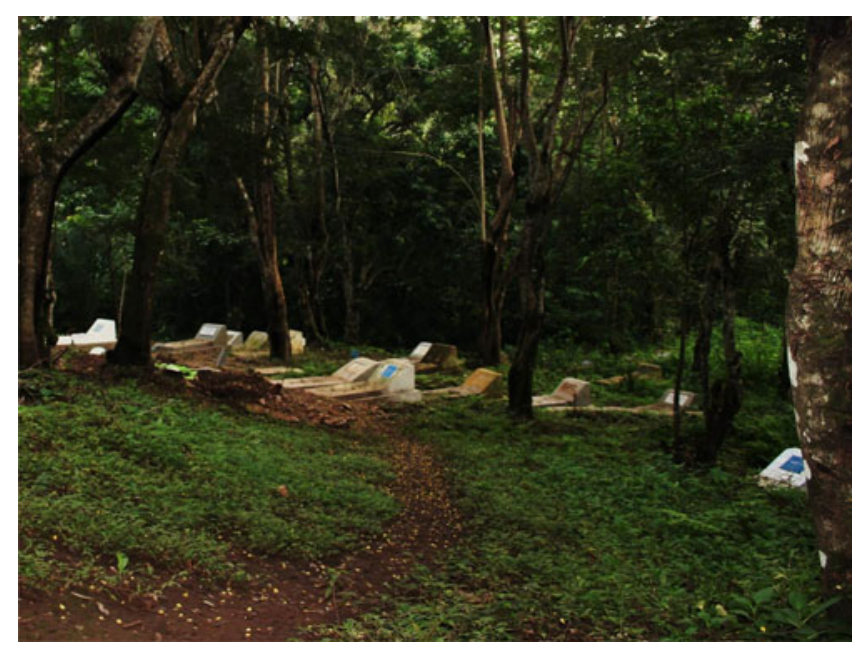

FIGURE 1. The graveyard area from Odo's story (extract (2)). 
body of the story (omitted here), Odo recounts how he carefully rounds the tree and attacks the snake with a cutlass. After some struggle, the snake uncoils and Odo delivers the final blow, as reported in line 29: 'and I- finally my hitting killed it'. After this climactic moment, Odo's multi-turn unit ends, providing an opportunity for recipients to respond to the story. This is the moment where the place reference from the story beginning proves relevant again, as shown by Koku's reponse: tsk (0.3) aye lalaà adé mmò lo 'tsk (0.3) bad snakes live there!' (line 31) and by Ruben's agreement with that point (line 32). Koku's statement underlines the ominous nature of the graveyard as a place where one encounters not just snakes, but 'bad' snakes, a description he repeats after the response token $m$ - hm by another story recipient (lines 32-34).

The initial place reference in the story beginning foreshadows something about the story to be told, and hence what kind of response will be relevant. We refer to this function of place reference as SETTING THE STAGE. The relevance of the graveyard area as the stage for a story about dangerous snakes is revealed by Koku, who orients to the relevance through a marked go-ahead response following the story beginning and displays his understanding of the connection between the graveyard area and 'bad' snakes at story completion.

A similar case is provided in extract (3). Speaker Luis projects the beginning of a story by mentioning that he has heard about something, and then begins to tell the story with a reference to activities set in a forest (lines 3-5). This beginning is followed by a go-ahead response (line 8 ).

(3) 'Three men went to the forest', CHSF2012_08_05S3_101670 (Cha'palaa)

$1 \quad(($ unrelated talk))

$2 \quad(1.9)$

3 Luis: i-yaa kuinda mi-ja-mi-ya

1-FOC tell know-come-DCL-FOC

'I heard tell $\{$ that $\}$ '

4 (1.9)

5 ma- pen ru-ku-la jele ne-mu-la-a uma kepenene

one- three man-COL forest walk-NMLZ-COL-FOC now morning awendyushu boar

'three men went to the forest, early, a boar,'

$6 \quad(1.3)$

7 suu-kii-tu-ren [awendyushu

follow-do-become-DR-PREC boar

'following a boar'

8 Gonzalo:

[uwain

'right'

9 Luis: pai tyatyu ke-tu-n de-ka-tya-a de-ti-sh

two shoot do-SR-IPF PL-get-NEG-FOC PL-Say-EV

'They say they shot at two but did not catch them.'

10

((story continues)) 
The reference to the generic setting of 'the forest' helps to set the stage for a story concerning boar hunting, invoking an environment in which the hunters 'follow' and 'shoot at' the animal, activities that would not typically occur in other environments such as the town, the river, or the agricultural fields.

Additional evidence of the importance of place reference for setting the stage for stories comes from cases in which it is absent (cf. Sidnell 2010:181), and in particular from cases in which its absence is noticeable, as in extract (4), where a listener interrupts a story to ask for its spatial anchoring. Lucia begins a story in lines 2 to 4 , specifying a time (by means of verbal tense) and a person (by means of recognitional references to Ezequiel and his wife), but not a place.

(4) 'There downriver', Cha'palaa (CHSF2012_08_04S3_820570)

$1 \quad(4.0)$

2 Lucia: tsei-'mityan (.) ezequiel(.) ura supu-n chu (1.0)

like.that-because Ezequiel good woman-A sit

'That is why (I say) (.) Ezequiel (.) his wife really (1.0)'

3

supu-bain (1.3) ji-' mi'ka-lare-' supu-aa mi'kalare' ji-n-tu (.)

woman-also go-seek-CAUS-SR woman-FOC seek-CAUS-SR go-IPF-SR

'his wife also (1.3) (he) went and called (his) wife'

4

umbee-na ji-n-tu

man-small go-IPF-SR

'as the young man went,'

5 Dalia: nuka-a tsa-dei-n juntsa-la

where-FOC like.that-PL-become that-COL

'where did that happen with them?'

$6 \quad(0.2)$

7 Lucia: anka-a pele-sha ((lip+gaze point))

there-FOC downriver-LOC

'there downriver' ((lip + gaze point))

8 Sandra: yei-la-' junka-a

3-COL-POSS there-FOC

'at their place'

9 Dalia: ya-'-ma-la junka ji-nu-u-shee

3-POSS-mother-COL there go-INF-be-Ev

'she really should have gone to her mom's place'

10 Lucia: ya ba-li-' jinu ya naa chu-'-ba ji-mu-u

3 go.down-go.in-SR go-INF 3 how sit-SR-also go-AG.NLMZ-Q

'having gone down there like that, how could she go also \{to her mother's\}?'

11 Dalia: $\mathrm{mm}$

'yeah'

12 Lucia: i-ya ba-li-' ji-mi tse junka ...

1-FOC go.down-do.in-SR go-DCL like.that there

'as for me, if (she) went there like that' ((continues)) 


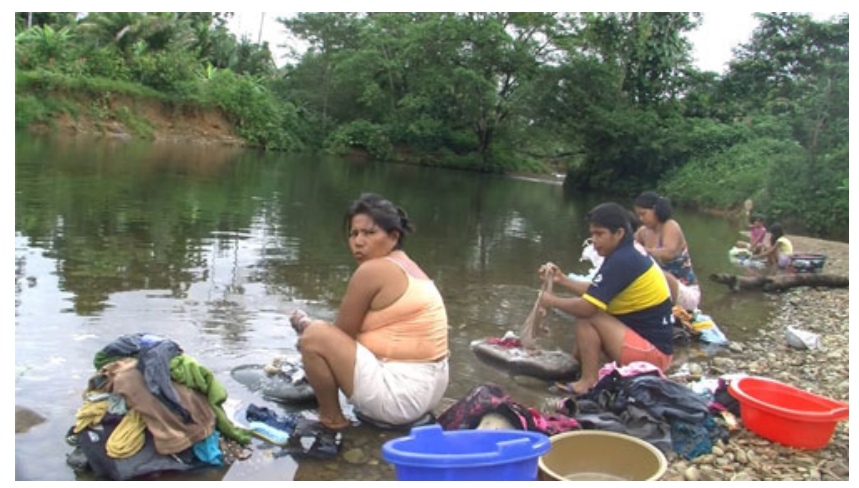

FIGURE 2. 'There downriver' ((lip+gaze point)) (extract (4), line 7).

Lucia begins telling a story, but is soon interrupted by Dalia, who asks 'Where did that happen with them?' (line 5). This where-question shows the recipient's orientation to place reference as a required feature of this story beginning (Sidnell 2010:179-80), the initial absence of which is noticeable and needs to be repaired. The subsequent clarification delays the continuation of the story by starting a side sequence (Jefferson 1972). In the next turn, Lucia provides the place reference: 'There downriver,' combined with pointing by gaze and lips (line 7). Then, Sandra also steps in to help clarify: 'at their place'. These responses pave the way for the resumption of the story. Before this happens, however, Dalia offers an opinion about where the protagonist should have gone instead (line 9), adding further reasons for the relevance of place in this story and also demonstrating her membership as a recipient 'in the know' (for further discussion of the relation between knowledge and membership in storytelling, see Sidnell 2000). With the missing place reference properly dealt with and the stage fully set, Lucia resumes the telling of the story.

\section{Making the story cohere}

So far we have focused on one first affordance of place reference in story beginnings: setting the stage, where referring to place helps to signal that a story is being launched and to show what kind of story it is. In this section, we show that place reference does further anchoring work, by providing a reference point for subsequent elements and developments of the story. We refer to this function as MAKING THE STORY COHERE.

In extract (5), Fedro is talking with Romeo about his touchscreen mobile phone, which he has recently acquired from another member of his family (lines 1-2). As Fedro begins to evaluate his new phone (line 5), he launches a story to demonstrate the main disadvantage of a touchscreen, namely that the keypad cannot be felt with fingertips, which makes it difficult to use the phone in situations of poor visual access. 
(5) 'I got to the top of Holy Hill', CampFamTavolo_414710 (Northern Italian, Italy)

1 Fedro: nient no lo vol nesuni l'è arinothing not 3 s.A want -3 s nobody 3 s.SCL $=$ be. 3 s arrive-PSTP l'è arivà a mi

$3 \mathrm{~s} . \mathrm{SCL}=$ be. $3 \mathrm{~s}$ arrive-PSTP to $1 \mathrm{~s} . \mathrm{D}$ 'nothing, nobody wants it, it go- it got to me' dopo aver fat el giro de tuta la famiglia after have-INF make-PSTP the round of all the family 'after it was passed on by everyone else in the family'

3 Romeo: ma dai but PCL 'no way!'

$4 \quad(0.6)$

5 Fedro: è scomodi- cè no mi 'l trovo anca [comodo be. $3 \mathrm{~s}$ inconvenient-suP PCL no 1s.N 3s.A find-1s also handy 'it's very inconvenie- I mean well for one thing I find it handy'

6 Romeo: [li è comodi 3P.SCL be.3P handy 'are they handy?'

7 Fedro: ma som arivà 'n zima a- al al but be.1s arrive-PSTP in top at at-the at-the 'but I got to the top of the the the'

$8 \quad(0.4)$

9 Fedro: a mm mm 'n zima $\mathrm{mm}$ en mes fa che son nà a far at in top one month ago LNK be.1s go-PSTP to do-INF na sciadina one skiing-DIM 'the $\mathrm{mm} \mathrm{mm}$ to the top $\mathrm{mm}$ a month ago when I went skiing'

10 som arivà 'n zima al Col Sant be.1s arrive-PSTP in top of-the NAME 'I got to the top of Holy Hill'

$11 \quad(0.5)$

12 Fedro: no vedevo niente not see-IPF-1s nothing 'I couldn't see anything'

$13 \quad(0.5)$

14 Fedro: ho p-pigià per per veder se riuscivo a far have-1s press-PSTP for for see-INF if manage-IPF-1s to make-INF 'na telefonada one call 'I p- pressed to to see whether I could make a call'

15 ala Loretta dela serie vara che fra ' $n$ oreta doe som to-the NAME of-the series look-IMP.2s CMP within one hour two be.1s a casa at home 'to Loretta, of the kind "In an hour or two I'll be home", 
16

17 Fedro: boh niente vabè alora vai in mosca

PCL nothing PCL then go-NPST-2s in fly 'dunno, never mind then, to blazes!' la Loretta che che no so perché the NAME REL REL not know-1s why 'it was Loretta who who I don't know why' dala scarsela pronto: pronto:: put-1s in pocket and perceive-1s from-the pocket ready ready 'I put it in my pocket and hear from the pocket "hello: hello::"' ho fat- ho ciamà l'ho ciamada have-1s make-PSTP have-1s call-PSTP 3s.A = have-1s call-PSTP ma no so c ome but not know-1s how 'I did- I called her but I don't know how'

At line 7, Fedro launches a story about an event taking place when he got to the top of a mountain. As he formulates the name of the place, however, he runs into a disfluency or hesitation ('I got to the top of the the the the $\mathrm{mm} \mathrm{mm}$ to the top $\mathrm{mm}$ ', lines 7 and 9). One of the possible reasons for this is that Fedro may be unsure about which reference form to use (the name of the mountain or of the particular peak). Whatever the reason, this prolonged hesitation gives him the opportunity to insert two other elements into the story beginning: a time reference ('a month ago') and the activity he was involved in ('when I went skiing'), after which he reformulates the place reference and completes it with the name of the peak he had climbed: Col Sant 'Holy Hill' (line 10).

Situating the events on a mountain peak serves the coherence and contextualisation of Fedro's story in at least two ways. For one thing, it helps to make sense of why all of a sudden Fedro 'couldn't see anything' (line 12), the reason being that mountain peaks can quickly become very foggy, especially during winter. At the same time, the reaching of a mountain peak means that Fedro's hike is at its culmination. This explains why he would make a call to his wife at that point to give her an estimate of when he is going to be back home (lines 14-15).

The punch line of the story is that, shortly after Fedro gives up trying to start the call (line 17) and puts the phone back in his pocket (line 18), he hears his wife's voice coming out from the pocket ('hello: hello::'), showing that he had after all managed to start the call even though he couldn't see the keypad (lines 19-20).

So situating what happened to Fedro 'on the top of Holy Hill' helps the understanding of two core components of the unfolding story: his inability to see the phone's keypad and the making of a call to his wife to tell her that he is going to be home soon.

The next case sheds further light on the relation between place reference and story structure by illustrating the consequences of failing to situate events in their appropriate places. Romeo has been talking about his brother, who is an eccentric man with a passion for animals. At line 5, Romeo launches a story about the 
domestic animals that his brother used to keep when they lived together with their parents, including a dog, chickens, rabbits, and a horse (the story is part of a series of stories illustrating the brother's love for animals). As the different animals are introduced into the story in chronological order, Romeo's recipients react humorously to his apparent failure to situate the adoption of different animals in different places.

(6) 'Still in the condominium?', CampFamTavolo_2230346 (Northern Italian, Italy)

1 Enzo: sto chi l'è 'l to fradel dei animali this here $3 \mathrm{~s} . \mathrm{scL}$ be.3s the your brother of-the animals 'this guy is your animal-loving brother?'

2 Romeo: sì

3 Enzo: eh

$$
\text { 'yes' }
$$

INTJ

'right'

4 Emilia: ((laughs))

5 Romeo: dopo sen nadi [en condomafter be.1P go-PSTP in condominium 'then we moved into a condom-'

6 Enzo: [ma vedet l'è emprinting but see- $2 \mathrm{~s}=2 \mathrm{~s} . \mathrm{sCL} 3 \mathrm{~s} . \mathrm{SCL}=$ be. $3 \mathrm{~s}$ imprinting 'see? It's imprinting'

$$
\text { l'è dal'ini[zio che (l'è un) }
$$

$3 \mathrm{~s} . \mathrm{SCL}=$ be $.3 \mathrm{~s}$ from-the $=$ beginning that $(3 \mathrm{~s} . \mathrm{SCL}=$ be $.3 \mathrm{~s}$ one $)$ 'it's from the beginning (that he is)'

8 Romeo:

[sen nadi en condominio be.1P go-PSTP in condominium 'we moved into a condominium'

$9 \quad(0.6)$

10 Romeo: e l'ha comprà en caign el l'ha and $3 \mathrm{~s} . \mathrm{SCL}=$ have- $3 \mathrm{~s}$ buy-PSTP one dog $3 \mathrm{~s} . \mathrm{A} 3 \mathrm{~s} . \mathrm{SCL}=$ have- $3 \mathrm{~s}$ 'and he bought a dog, and'

$11 \quad(0.3)$

12 Romeo: e l'ha met- l'ha mes and $3 \mathrm{~s} . \mathrm{SCL}=$ have- $3 \mathrm{~s}$ put $-3 \mathrm{~s} . \mathrm{SCL}=$ have- $3 \mathrm{~s}$ put-PSTP 'and he put it, he put'

$13 \quad(0.9)$

14 Romeo: en del condominio gh'era sto caign e nesuni e in the condominium $\mathrm{EX}=$ be.IPF- $3 \mathrm{~s}$ this dog and nobody and 'in the condominium there was this dog and nobody and' uh uh capì uh uh understand-PSTP 'uh uh do you understand?' (0.4) 
17 Romeo: cè l'è

PCL 3s.SCL $=$ be. $3 \mathrm{~s}$

'I mean it's'

$18 \quad(0.3)$

19 Romeo: le galine 'the chickens'

20 Emilia: ((chuckles))

21 Romeo: e i cunei 'and the rabbits'

22 Romeo: cè l'è sempre sta così per cui heh heh PCL 3s.SCL = be.3s always be-PSTP like.this for which 'I mean he's always been like this therefore heh heh' (4.6)

24 Romeo: finché l'è arivà 'l caval until $3 \mathrm{~s} . \mathrm{SCL}=$ be. $3 \mathrm{~s}$ arrive-PSTP the horse 'until the horse arrived' $(0.3)$

26 Romeo: [sogno dream 'the dream \{of his life $\}$ '

Emilia: [((smiles $))$

$28 \quad(0.6)$

29 Plinio: $\mathrm{n}$ - nel condominio sempre in-the condominium always 'still in the condominium?'

30 Mario: [mmmmh

31 Emilia: [((laughs))

32 Romeo: no no no ( ) no no no ( )

33 Mario: ((laughs))

34 Romeo: ( )

35 Emilia: ((laughs)) (i) feva un po' fadiga a farlo (3P.SCL) make-IPF-3P one bit fatigue to make-INF $=3$ s.A 'it was a bit difficult to'

entrar la sera enter-INF the evening 'squeeze it back in at night'

Fedro: sì e soprattutto a sconderlo ai condomini i yes and above. all to hide-INF $=3$ s.A to-the neighbours 3P.SCL feva fadiga make-IPF-3P fatigue 'yes and above all it was a bit difficult to hide it from the neighbours'

After a brief interruption (lines 6-7), Romeo restarts the story: 'we moved into a condominium and he bought a dog'. He then reiterates the two basic elements of the story - the fact that his family lived in a condominium and the fact that the 
dog was with them in the flat — but without adding much development and leaving two units unfinished ('he put', line 12, 'and nobody and', line 14). At this point, he proceeds to seek uptake ('do you understand?', line 15), plausibly expecting listeners to recognise the bizarre contradiction in his brother's behaviour: he wanted a dog so badly that he lost sight of the fact that a condominium (which offers only a limited living space) may not be the right home for a dog. As no uptake comes from his listeners, Romeo introduces other animals that his brother used to keep (chickens and rabbits, lines 19-21), but without specifying where these other animals were kept. After a relatively long pause (line 23), Romeo adds yet another animal to the story: the horse - his brother's 'life dream'. The use of the deictic verb 'arrive' suggests that the horse was kept in the same place as the previous animals. And since Romeo hasn't resituated the events after setting the story in the condominium, an ambiguity arises as to whether the horse, too, was kept there. This is what Plinio picks up on at line 29, where he jovially asks whether what Romeo is telling took place 'still in the condominium'. This sparks the laughter of the other listeners and occasions further facetious comments on the unlikely case of a horse living in a condominium (lines 35-37).

To sum up, here the storyteller fails to resituate the events being told at a point at which this would be relevant. The lack of a reference to the place where the horse was kept creates an incoherence in the story. The recipients' responses draw attention to this, bringing to light the fact that subsequent elements and developments of a story continue to be understood by reference to the place specified at the beginning, unless noted otherwise. The possible incoherence here is first revealed by a question ('still in the condominium?'), which elicits laughter from Emilia. Despite Romeo attempting to quickly resolve the problem with a negative answer ('no no no'), the incoherence attracts further banter. The recipients' behaviour here points to the normative nature of story composition, the coherence of which involves an adequate specification and tracking of place.

The cases discussed in this section show how place reference contributes to a story's coherence. Narrators can use references to places as a binding technique to introduce and contextualise other elements and developments of the story. Recipients orient to this function by tracking where different events happen and by pointing out potential incongruities.

\section{Underspecified and implied place reference}

The place where a story is set is not always explicitly referred to at its beginning. Sometimes it is underspecified or simply absent (see Table 1). Although such absences may be noticeable and lead to interactional trouble, as in extract (4) above, often enough they seem to pose no problem. How do participants deal with this? Let us start with a story beginning featuring a maximally underspecified place reference: 'wherever'. 
In Extract (7), Aku and Beatrice are outdoors in Beatrice's compound. Beatrice is stirring some palm fruit pulp in a pot on the fire. Aku is sitting a short distance away from her when she begins a telling.

(7) 'The other day, wherever I was', Palmoil_4_1853675 (Siwu, Ghana)

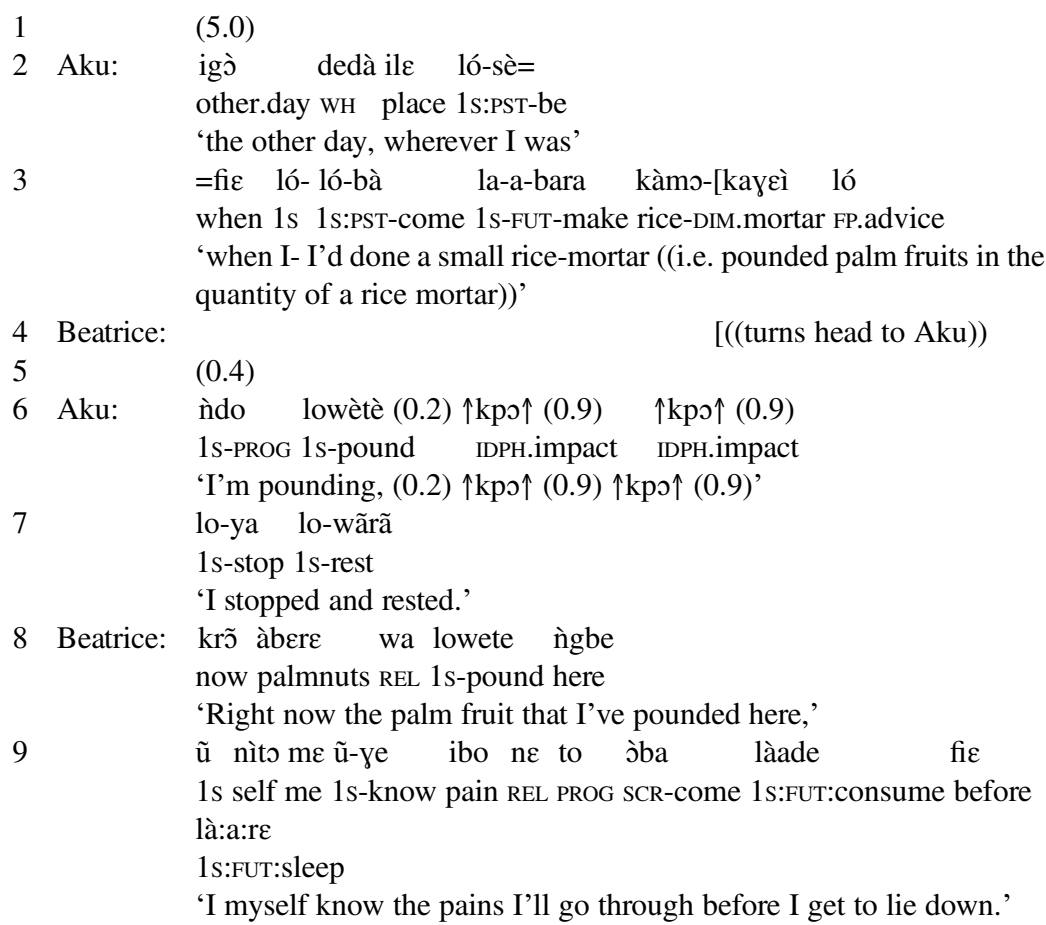

In beginning with 'the other day, wherever I was', Aku refers to a time, a person, and a very underspecified place: 'wherever', an expression composed of the generic content question word deda and the word for 'place' ile. When she adds more information about what she had been doing, Beatrice turns her head to look at Aku, displaying her orientation to the telling-in-progress (lines 3-4). Aku produces a laborious re-enactment of the heavy work of pounding palm fruits to make oil, then notes how she had to stop and take a rest (lines 6-7). In response to this, Beatrice produces a second story, beginning with another time-personplace triad: 'right now the palm fruit that I've pounded here' (line 8). Second stories display an analysis of the point of the previous story (Sacks 1992a:765). By referring to the heavy labour and the toll it takes ('I myself know the pains I'll go through before I get to lie down', line 9), Beatrice affiliates with the stance expressed in Aku's story, revealing an understanding of the trouble and 
thereby displaying her analysis of Aku's story as an instance of troubles-talk (Jefferson 1988).

In these two brief tellings, place is not made interactionally relevant in the same way that we have seen in the previous sections. In the first telling, it is hard to see how the indefinite expression 'wherever' could set the stage; if anything, it disclaims the relevance of place for the unfolding story. Beatrice's second telling is about what she has just finished doing, suggesting her understanding of the previous story as being relevant for the labouring of participants here and now (quite literally: 'right now' and 'here' are built into her story beginning). Indeed, for about an hour before extract (7) begins, Beatrice has pounded and processed two full baskets of oil palm fruits, during which Aku has been present all the time. Setting the stage is therefore unnecessary: the speakers already inhabit it, with the relevant actors and activities present before their eyes.

In sum, underspecification of place does not necessarily prevent recipients from making sense of a story. Such underspecification happens when the story is anchored in the here and now, and recipients can infer relevant activities and actors from the current situation.

Extract (8) makes visible the interactive retrieval of relevant story elements following an underspecified initial reference. Elia launches a story by appealing to the shared memory of a 'memorable discussion' ('you remember that memorable discussion: right?', line 2), a device proposing the event as tellable to the others present. Elia's initiating turn does not specify a place for the memorable discussion, nor the people involved in it. In what follows, Dino and Rosa display shared knowledge of the events, casting themselves as co-tellers with Elia. All three co-tellers contribute to specifying elements of person and place in order to share the events with others who were not present at the time. In the target line 7, Elia uses the deictic locative $l i$ 'there', accompanied by a pointing gesture, to refer to the chair on which Rosa is sitting - the exact place from which he once delivered the memorable joke that is the kernel of the story.

(8) 'I was even sitting there', Letto-Ed_513961 (Italian)

$1 \quad$ ((unrelated talk))

2 Elia: ti ricordi quella mitica discussione: vero

2.D remember-2s that legendary discussion true 'you remember that memorable discussion: right?'

3 Dino: è vero è vero me la ricordo ( ) la Rosa(hh)

be. $3 \mathrm{~s}$ true be. $3 \mathrm{~s}$ true $1 \mathrm{~s} . \mathrm{D} 3 \mathrm{~s} . \mathrm{A}$ remember-1s ( ) the NAME 'right right I remember ( ) Rosa(hh)'

4

(.)

5 una delle tue battute migliori Elia

one of-the your jokes better NAME

'one of your best jokes Elia' 
6 Rosa: esatto che bello::: [eravamoexactly what beautiful be.IPF-1P 'that's right, how great::: we were-"

7 Elia: [ero anche seduto lì ((points to chair)) be.IPF-1s also seated there 'I was even sitting there'

8 Rosa: eravam- esatto sì eravamo: io la Viola la Serena be.IPF-1P exactly yes be.IPF-1P 1S.N the NAME the NAME 'we wer- yeah that's right, it was me, Viola, Serena'

Together with the previous example, extract (8) shows that people may draw on the here and now — on the actors and activities connected to the current situationto resolve minimal or underspecified place references and situate the unfolding story.

Another way to make sense of underspecified place references is by drawing on places mentioned in prior talk. Extract (9) involves three people: a child named Leo, his dad, and his uncle. Before the extract begins, Uncle has complimented Leo on winning a board game they played together a couple of weeks before. To put Uncle's praise into perspective, Dad has then mentioned another game of the same kind - in which Uncle did not participate - that had to be suspended due to Leo's unfair play. As Dad goes on to describe Leo's reckless moves during the game, an ambiguity arises as to which game he is referring to, and the people that participated in it. This causes Uncle to initiate repair on Dad's talk (lines 4 and 8), to which Dad responds by beginning a proper telling of the suspended game (lines 9-10).

(9) 'Did he come to play Risk?', Fratelli_1690583 (Italian)

1 Dad: ma c'è il figlio di Luigi che era l'altro giocatore but EX $=$ be. $3 \mathrm{~s}$ the son of NAME REL be.IPF- $3 \mathrm{~s}$ the $=$ other player 'but there's also the son of Luigi, who was the other player,' si chiama Zorro pure lui ((to Leo)) IM call-3s NAME also 3s.N 'whose name is Zorro too'

$3 \quad(0.3)$

4 Uncle: ma- (0.3) altro giocatore 'but- $(0.3)$ other player?'

$5 \quad(1.7)$

6 Dad: Luigi Solenghi NAME SURNAME 'Luigi Solenghi' $7 \quad(1.2)$

8 Uncle: avete- è venuto [a giocare a Risiko have-2P be.3s come-PSTP to play-INF to Risk 'did you- did he come to play Risk?' 
9 Dad:

[abbiam fatto una partita l'altro giorno have-1P do-PSTP one match the $=$ other day

'we had a game the other day'

10

con Luigi (0.5) Zorro (0.5) e Cosimo

with NAME NAME and NAME

'with Luigi (0.5) Zorro (0.5) and Cosimo'

11 Uncle: ma dai

but PCL

'how cool!'

The deictic verb venire 'come' contained in Uncle's second repair initiation ('did he come to play Risk?', line 8) indicates his understanding that the suspended game took place in Leo's house, the same place of the previous game, and also the place where the current interaction is happening. So, when Dad begins to recount the suspended game in detail ('we had a game the other day with Luigi, Zorro and Cosimo'), he can assume that the place of the story is part of their common ground, and omit it from the beginning.

Not mentioning or specifying the place where something happened may have different reasons, but two recurrent nonexclusive ones are that (i) the place is the same as where the story is being told, and can be retrieved from the here and now, and (ii) the place can be inferred from prior talk. Minimal, underspecified or absent place references are quite common in story beginnings in our sample. This can plausibly be related to the omnirelevance of the here and now in informal face-to-face social interaction and to people's tracking of reference across related spates of talk.

\section{ELEMENTS OF L INGUISTIC FORMAT T ING}

We began by noting that references to place are charged with interactional and cultural meaning, and are far more than neutral, decontextualised locators. In a seminal study of place formulation, Schegloff (1972) observed that place references in interaction reveal and afford three kinds of analysis: (i) a location analysis, concerning the relation between the place reference and the location referred to; (ii) a membership analysis, concerning the social relations and epistemic positions of participants in the interaction (e.g. whether they can be expected to know the place by this reference); and (iii) an activity analysis, concerning the relation of the linguistic formatting and the larger social action it contributes to in the interaction. The analysis above has shown how people orient to each of these aspects of place reference in interaction, and more generally how referring to place helps shape unfolding stories.

The interactional affordances of place reference are supported by their linguistic design. In the story beginnings in our sample, place references are built out of five broad types of linguistic devices, which occur in all of the languages: deictics 
('here', pointing gestures), proper names ('Holy Hill'), place-through-person ('the late Porfirio's place'), settings ('graveyard area'), and spatial relational terms ('in', 'at', 'the top of', 'around', and equivalents). These formats do not exhaust all of the linguistic options for formatting place reference (as catalogued in e.g. Schegloff 1972 and Levinson \& Wilkins 2006). Other forms of reference such as street addresses are useful for locating buildings in the absence of detailed local knowledge, but precisely because of that they are less useful for setting the stage of a story (unless they become more than just an address by virtue of common knowledge, as in Downing Street 10). Micro-scale locational formulations like on your left cheek or in the cupboard can be useful to make noticings or requests - to point out that a friend has some food on their face or to tell another where to get the plates - but are unlikely to afford either the stage-setting or coherence-building uses of place references in story beginnings. The kind of linguistic formats we find in story beginnings help shape the storytelling activity and are at the same time constrained by it.

Inventories of linguistic practices for referring to place will always show a degree of language-specificity. For instance, languages differ in the type and amount of demonstratives they make available; and one language's locative postpositions may be another's nominal classifiers. It is possible that such differences have implications for the interactional work that can be done with place reference, although we have not seen evidence of this in the context of story beginnings in these three languages. The linguistic diversity is structured along several dimensions that are applicable across languages. Two such dimensions that are interactionally relevant for place reference are the degree to which the referring expression pinpoints a specific site versus a generic scene (location vs. setting), and the degree to which its recognisability is limited to a subset of members (recognitional vs. nonrecognitional).

First, place references may differ in extent to which they specify a place or invoke activities and actors (Enfield 2013). Some references are primarily LOCATIONs: they tell you where something is. Examples are street addresses or coordinates, though more typical in stories are waypoints like the southern gate or demonstratives like here. Other references are primarily sETTINGS: they invoke activities and actors. Typical examples are in town or the forest. Locations and settings are not always clearly distinct, and indeed many place references combine elements of both. Figure 3 illustrates these overlapping sets with place references from the story beginnings analysed above.

In story beginnings, we often encounter place references that combine aspects of locations and settings. The 'graveyard area', for example, is a known location to the participants in the Siwu extract (2), but at the same time also a setting for ominous encounters. Similarly, 'the top of Holy Hill' in the Italian extract (5) pinpoints a particular mountain peak, but also serves to anchor the narrative as relevantly happening in a foggy place. At the extremes of the location-setting continuum we encounter place references that leave either location or setting open. A place reference like 'here' used in context with a pointing gesture is very specific in 


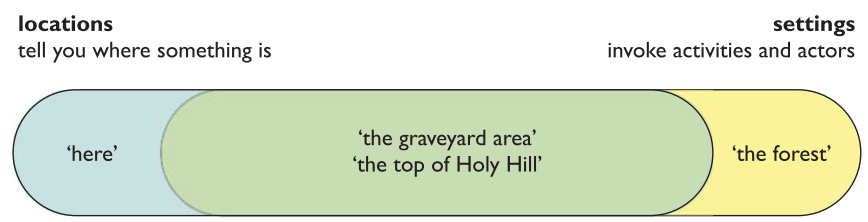

FIGURE 3. Locations and settings.

pinpointing a location, but leaves open relevant activities and actors. In contrast, a generic setting like 'the forest' may invoke typical activities and actors, while leaving open the precise location. In both cases, what is left open or underspecified can be resolved or retrieved in other ways. As we saw above, specification may be requested by recipients or volunteered by storytellers as the story develops, or it may be left to inferences supported by context and common ground.

Orthogonal to the distinction between locations and settings is a contrast between RECOGNITIONAL and NONRECOGNITIONAL references (Schegloff 1972; cf. Enfield \& Stivers 2007 for analogous observations in the domain of person reference). Recognitionals are references like proper names, whose resolvability depends on the ability of recipients to identify the unique referent. Nonrecognitionals are references like here, that can be used 'by any speaker for any recipient about any referent' (Sacks \& Schegloff 1979:17). The status of a place reference as recognitional or nonrecognitional is to an important degree an interactional and interpersonal matter that can only be decided on the basis of participants' orientations. Some linguistic formats, however, are by design more recognitional than others. Proper names like Col Sant 'Holy Hill' (extract (5)) or Pacific Palisades (Sacks 1992b:141) are prototypical instances of recognitionals, as they require local members' knowledge to be connected to actual places: nonmembers of the relevant communities are unlikely to know that they refer to a mountain peak in Northern Italy and to a neighbourhood in Los Angeles, respectively. In contrast, demonstratives or generic terms like outdoors do not require the same kind of detailed local knowledge.

Given these two dimensions (location/setting and recognitional/nonrecognitional), we can better understand the referential choices people make in story beginnings. Sacks already showed that people use initial place references as an anchor for subsequent place references, which are often parasitic on the first (like the demonstratives in the graveyard stories). Here we have seen that initial place references also provide an anchor for other story elements, by providing fertile ground for listeners' inferences, expectations, and interpretations about the unfolding story. Since settings tend to evoke activities and actors, they are particularly useful for the function of setting the stage. By contrast, recognitional references to locations mobilise members' knowledge, as in the village graveyard that is known to harbour bad snakes (extract (2)), or the nearby peak that is known to be foggy (extract (5)). The specific features of these places can be mobilised for the interpretation of story elements that would be otherwise unexpected. 
Let us examine a final example demonstrating how the cross-cutting dimensions of setting/location and recognitional/nonrecognitional are mobilised in interaction. The case is complex, involving a story with multiple false starts, so it allows us to take a closer look at the interactional challenges of beginning to tell a story. Some women are chatting while processing maize. The conversation has turned to the topic of distant husbands, and Charlotte discusses how she tried to convince a man to leave Tema and Accra (places in the south of Ghana) and 'come to our Akpafu town here' - the same place where the interaction takes place. After contributions by Doris and Aku, Beatrice starts something new at lines 5-6 that looks like a story beginning - but she has trouble securing the floor to continue to tell the story.

(10) 'The Juapong one', Maize1_363152 (Siwu)

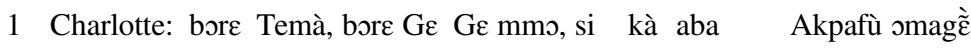
leave PLN love PLN PLN there LNK ING 2s:come PLN town ame ngbe inside here 'leave Tema, get out of Accra there, and come to our Akpafu town here'

2 Doris: oo:, leì to lò ba INTJ 1s:NEG PROG 1s come 'oh, I'm not coming'

3 kuэw ்̃ na mè mmò. no.one lack inside here 'there is no one here for me.'

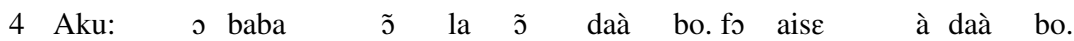
3s PLUR come 3s:TP keep 3s:TP bother 1P you 2s:NEG:HAB 2s bother 1P 'He might come and bother us. You won't bother us.'

5 Beatrice: gó ló sè ipo àméwhen 1s:PST go bush inside

'When I went into the bush'

6 [ló di ayatà.

1s:PST pluck leaves

'I was plucking leaves.'

7 Doris: [mè lo di ĩ̀ òri, síloò ba kere lo fo me $1 \mathrm{~s}$ give $3 \mathrm{~s}$ way if $1 \mathrm{~s}:$ PF come just $1 \mathrm{~s}$ collect

'I've let him go, when I return I'll pick him up again'

8 Aku: oò wo! ì̀à lé.

INTJ INTJ it:NEG:FUT be.good

'Oh no, that isn't good.'

9 Charlotte: $\varepsilon \varepsilon, \tilde{\varepsilon} h \tilde{\varepsilon}$

yes INTJ.uhuh

'Yeah, go on.'

10 Doris: te ià $l \varepsilon$.

PROG it:FUT be.good

'Oh, it's good.' 
11 Aku: oo, iì̀ $\quad l \varepsilon, \quad n \varepsilon$ oso ne:no it:NEG:FUT be.good TP reason TP 'No, it's not good, because-'

$12 \quad(0.3)$

13 Beatrice: m̀ma kosò!

kin.F junior

'Junior sister!'

14 Aku: ̀ma

kin.F

'Sister.'

15 Beatrice: kà lòba làpqgu Juapong ire ló ING 1s.come 1s.FUT.hit PLN one FP 'I'm getting to the Juapong one, okay?'

16 Aku: ãi

yes

'yes'

17 Beatrice: kù go ló sè ipo ame how when 1s:PST go bush inside 'about how I went into the bush'

18 Aku: ãi

yes

'yes'

19 Beatrice: gó mè so laà di ayata. when 1s:IND QT 1s:FUT pluck leaves

'how as I said I was going to pluck leaves'

20 Aku: ãi, kà pqgu sí bonò. yes ING hit LNK 1P:listen 'yes, get to it so that we listen'

21 Beatrice: fie [foòfo nethen not.knowing TP 'Not knowing-'

22 Doris: [((laughter))

23 Beatrice: si kà mìlo si minò ló LNK ING 2P:be.silent LNK 2P:listen FP.advice 'Please be silent and listen, okay?'

24 Aku: $\quad[\mathrm{mm}$

INTJ

'mm'

25 Charlotte: $[\mathrm{mm}$

INTJ.continuer

'mm'

26 Beatrice: mè lota igò ìwz̃ so laà di ayata 1s:IND 1s:get.up day one QT 1s:FuT pluck leaves 'so I get up one day in order to pluck leaves' 
27 Aku: $\quad \mathrm{m}-\mathrm{hm}$

INTJ

'm-hm'

28

ne lòse $n \varepsilon$, foòfo $n \varepsilon$,

TP 1s:go TP not.knowing TP

'and I was walking, not knowing,'

29

((story continues))

Beatrice's turn at line 5, 'when I went into the bush', has all the features of a typical story beginning: it mentions person, time, and place and is designedly incomplete, making relevant a continuation. However, the continuation is fully overlapped by a contribution by Doris to the prior sequence, which in turn is responded to by Aku (lines 7-8), with the effect that two out of three members of the potential audience for Beatrice's story are still involved in another conversational sequence. Charlotte does provide a go-ahead response to Beatrice's story beginning: 'yeah, go on' (line 9), resulting in a schism (Egbert 1997). This continues with Doris and Aku going on with their sequence (lines 10-11). At line 13, Beatrice seizes the opportunity provided by a brief silence in Aku's unfinished turn to issue a summons to her: 'Junior sister!', to which Aku answers positively, abandoning the schism she formed with Doris. Having succeeded in drawing Aku's attention, Beatrice now announces the possibility of a story more explicitly: 'I'm getting to the Juapong one, okay?' (line 15).

This turn by Beatrice is a case of 'reformulating place' (Kitzinger, Lerner, Zinken, Wilkinson, Kevoe-Feldman, \& Ellis 2013), and its design needs a bit of unpacking. First, Juapong is a proper name, specifically the name of a place quite some distance south of where the story is being told. Whereas the setting 'into the bush' in the initial story beginning (line 5) did very little to tie the story to the prior talk, this place reference helps establish the possible relevance of the story in the context of a conversation that already involved several other far-away places identified by name. Second, Beatrice specifically uses the recognitional nature of the place reference to appeal to Aku and secure her involvement in the storytelling: 'the Juapong one' implies not just that Aku will know where Juapong is and what kind of a place it is, but also that Aku, unlike the others, has access to the events and may be able to confirm their tellability. That is exactly what happens: Aku aligns with the storytelling activity by responding affirmatively, first to Beatrice's announcement of 'the Juapong one' (lines 15-16), then to two subsequent turns in which Beatrice further specifies the setting (lines 17-18) and the activity (lines 19-20). The latter affirmation comes with a highly explicit go-ahead response 'yes, get to it so that we listen' (line 20) through which Aku can be seen to orient to the problems with recipiency encountered earlier.

Zooming out a bit, a few more things are notable about this case. First, settings like 'into the bush' may be useful to set the stage (indeed we saw similar examples in extracts (2) and (3)). But if they do not clearly tie to the preceding activity, the 
tellability of a story may be in doubt and the story may not be able to get off the ground, especially when the beginning of the story is in competition with another concurrent sequence. Second, a proper name - as a recognitional reference - can help to establish tellability both by linking back to prior talk and by appealing to people in the know. Third, proper names, because of their locational properties and their direct link to members' knowledge, have a greater ability to uniquely identify stories; this is harder with settings due to their generic nature (as a parallel, try referring to a joke as the bar one). Fourth, once tellability is established with the help of the proper name, the stage is reset by reference to the setting ('bush'), which provides anchoring for the activity ('plucking leaves').

In sum, all place-reference formats offer their own combination of interactional affordances, and speakers flexibly use them to meet the needs and challenges of (co) telling a story in social interaction. Story beginnings are an important locus to observe this work being done, showing how place reference sets the stage and helps make stories cohere-and even how it can help establish tellability and be used to secure an audience, as in (10) above.

\section{O N C L U S I O N S}

Place references are formally diverse, culturally meaningful, and inferentially rich. In this article, we have focussed on a conversational context in which place references regularly occur, and we have traced their interactional affordances and linguistic formatting across three unrelated languages. When bundled with reference to time and person, references to places help signal that a story is being launched. As rich settings, they project what kind of story this is going to be and what kind of response is expected. As precise locations, they help anchor the events across the narrated world in which the story unfolds. As references that can be recognitional or nonrecognitional, they mobilise members' knowledge and help organise participation. Place references are often crucial components of story structure, providing the background for events to be understood. Failing to situate different events in their appropriate places can lead to a halt or incoherence in the story, with recipients asking for a missing reference to be provided or orienting to incongruity. These findings from Cha'palaa, Italian, and Siwu confirm and expand observations based on English stories by Sacks (1992) and Sidnell (2010:178-81). The convergent and cumulative nature of the findings demonstrates the robustness and replicability of comparative conversation analysis (Sidnell 2009).

Our study shows that stories in everyday conversation are a robust and promising locus for systematic cross-linguistic comparison, complementing prior research that has so far mainly focused on elicited narratives. It also affirms the importance of looking at stories in interaction, as participants' orientations to the tellability, congruity, and coherence of stories provide crucial evidence for the narrative and interactional affordances of place reference. Across the three unrelated languages studied here, the roles of place reference in story beginnings emerge as strongly 
similar, suggesting that the functions of setting the stage and making stories cohere are not just features of place reference in particular languages or cultures, but are fundamental to storytelling as a human activity.

\section{N O T E S}

*We thank Uwe-Alexander Küttner, Jack Sidnell, the audience at the 2013 Nijmegen workshop on Place Reference, and two anonymous reviewers for Language in Society for helpful comments. We are grateful to Nick Enfield for supporting most of this work through the ERC project Human sociality and systems of language use (ERC grant 240853). Funding at later stages has come from the Max Planck Society for the Advancement of Science, a Veni grant from NWO (to MD), and the Finnish Centre of Excellence in Research on Intersubjectivity in Interaction (for GR).

${ }^{1}$ Transcriptions for data extracts use conventions specified in Jefferson (2004); interlinear glosses follow the Leipzig glossing rules (Comrie, Haspelmath, \& Bickel 2004).

${ }^{2}$ Grammatical glosses in the extracts are given below:

$\begin{array}{llll}\text { 1P: } & \text { 1st person plural } & \text { LNK: } & \text { linker } \\ \text { 3P: } & \text { 3rd person plural } & \text { N: } & \text { nominative } \\ \text { 1s: } & \text { 1st person singular } & \text { NAME: } & \text { name } \\ \text { 2s: } & \text { 2nd person singular } & \text { NEG: } & \text { negation } \\ \text { 3s: } & \text { 3rd person singular } & \text { NMLZ: } & \text { nominalizer } \\ \text { A: } & \text { accusative } & \text { NPST: } & \text { nonpast } \\ \text { CAUS: } & \text { causative } & \text { PCL: } & \text { particle } \\ \text { CMP: } & \text { complementiser } & \text { PF: } & \text { perfective } \\ \text { COL: } & \text { collective } & \text { PL: } & \text { plural } \\ \text { D: } & \text { dative } & \text { PLN: } & \text { placename } \\ \text { DCL: } & \text { declarative } & \text { PLUR: } & \text { pluractional } \\ \text { DIM: } & \text { diminutive } & \text { POSS: } & \text { possessive } \\ \text { EV: } & \text { evidential } & \text { PROG: } & \text { progressive } \\ \text { EX: } & \text { existential marker } & \text { PST: } & \text { past } \\ \text { F: } & \text { feminine } & \text { PSTP: } & \text { past participle } \\ \text { FOC: } & \text { focus } & \text { Q: } & \text { question marker } \\ \text { FP: } & \text { final particle } & \text { QT: } & \text { quotative index } \\ \text { FUT: } & \text { future } & \text { REL: } & \text { relative } \\ \text { IDPH: } & \text { ideophone } & \text { SCL: } & \text { subject clitic } \\ \text { IM: } & \text { impersonal } & \text { SCR: } & \text { subject cross-reference } \\ \text { IMP: } & \text { imperative } & \text { SR: } & \text { same referent } \\ \text { INDEF: } & \text { indefinite } & \text { SUP: } & \text { superlative } \\ \text { INF: } & \text { infinitive } & \text { SURNAME: } & \text { surname } \\ \text { ING: } & \text { ingressive } & \text { TP: } & \text { topic marker } \\ \text { INTJ: } & \text { interjection } & \text { WH: } & \text { wh-question marker } \\ \text { IPF: } & \text { imperfect(ive) } & & \\ & & & \end{array}$




\section{MARK DINGEMANSE, GIOVANNI ROSSI AND SIMEON FLOYD}

\section{R E F E R E N C E S}

Bamberg, Michael, \& Alexandra Georgakopoulou (2008). Small stories as a new perspective in narrative and identity analysis. Text \& Talk - An Interdisciplinary Journal of Language, Discourse Communication Studies 28(3):377-96.

Barthes, Roland (1966). Introduction à l'analyse structurale des récits. Communications 8(1):1-27.

Basso, Keith (1984). Stalking with stories: Names, places, and moral narratives among the Western Apache. In Stuart Plattner (ed.), Text, play and story: The construction and reconstruction of self and society, 19-55. Washington, DC: American Ethnological Society.

Bloom, Paul; Mary A. Peterson; Lynn Nadel; \& Merrill F. Garrett (1996). Language and space. Cambridge, MA: MIT Press.

Bransford, John D., \& Marcia K. Johnson (1972). Contextual prerequisites for understanding: Some investigations of comprehension and recall. Journal of Verbal Learning and Verbal Behavior 11(6):717-26.

Bruner, Jerome S. (1991). The narrative construction of reality. Critical Inquiry 18(1):1-21.

Comrie, Bernard; Martin Haspelmath; \& Balthasar Bickel (2004). Leipzig glossing rules. Online: eva. mpg.de. https://www.eva.mpg.de/lingua/resources/glossing-rules.php; accessed December 12, 2016).

Dingemanse, Mark, \& Simeon Floyd (2014). Conversation across cultures. In N. J. Enfield, Paul Kockelman, \& Jack Sidnell (eds.), Cambridge handbook of linguistic anthropology, 434-64. Cambridge: Cambridge University Press.

; Seán G. Roberts; Julija Baranova; Joe Blythe; Paul Drew; Simeon Floyd; Rosa S. Gisladottir; Kobin H. Kendrick; Stephen C. Levinson; Elizabeth Manrique; Giovanni Rossi; \& N. J. Enfield (2015). Universal principles in the repair of communication problems. PLOS ONE 10(9). Online: https://doi.org/10.1371/journal.pone.0136100.

Egbert, Maria M. (1997). Schisming: The collaborative transformation from a single conversation to multiple conversations. Research on Language \& Social Interaction 30(1):1-51.

Enfield, N. J. (2013). Reference in conversation. In Jack Sidnell \& Tanya Stivers (eds.), The handbook of conversation analysis, 433-54. Malden, MA: Wiley-Blackwell.

$\longrightarrow$, \& Tanya Stivers (eds.) (2007). Person reference in interaction: Linguistic, cultural, and social perspectives. Cambridge: Cambridge University Press.

Ervin-Tripp, Susan M., \& Aylin Küntay (1997). The occasioning and structure of conversational stories. In Talmy Givón (ed.), Conversation: Cognitive, communicative and social perspectives, 133-66. (Typological studies in language 34.) Amsterdam: John Benjamins.

Georgakopoulou, Alexandra (2015). Small stories research: Methods - analysis - outreach. In Anna De Fina \& Alexandra Georgakopoulou (eds.), The handbook of narrative analysis, 255-72. Malden, MA: Wiley-Blackwell.

Goodwin, Charles (1984). Notes on story structure and the organization of participation. In J. Maxwell Atkinson \& John Heritage (eds.), Structures of social action: Studies in conversation analysis, 225-46. (Studies in emotion and social interaction.) Cambridge: Cambridge University Press.

(1995). The negotiation of coherence within conversation. In Morton Ann Gernsbacher \&

Talmy Givón (eds.), Coherence in spontaneous text, 117-37. Amsterdam: John Benjamins.

— \& John Heritage (1990). Conversation analysis. Annual Review of Anthropology 19:283-307.

Jefferson, Gail (1972). Side sequences. In David N. Sudnow (ed.), Studies in social interaction, 294-338. New York: MacMillan/The Free Press.

- (1978). Sequential aspects of storytelling in conversation. In Jim Schenkein (ed.), Studies in the organization of conversational interaction, 219-48. New York: Academic Press.

(1988). On the sequential organization of troubles-talk in ordinary conversation. Social Problems 35(4):418-41.

(2004). Glossary of transcript symbols with an introduction. In Gene H. Lerner (ed.), Conversation analysis: Studies from the first generation, 43-59. Philadelphia: John Benjamins. 


\section{PLACE REFERENCE IN STORY BEGINNINGS}

Kitzinger, Celia; Gene H. Lerner; Jörg Zinken; Sue Wilkinson; Heidi Kevoe-Feldman; \& Sonja Ellis (2013). Reformulating place. Journal of Pragmatics 55:43-50.

Kuipers, Joel C. (1984). Place, names, and authority in Weyéwa ritual speech. Language in Society 13 (4):455-66.

Labov, William, \& Joshua Waletzky (1967). Narrative analysis: Oral versions of personal experience. In June Helm (ed.), Essays on the verbal and visual arts: Proceedings of the 1966 Annual Spring Meeting of the American Ethnological Society, 12-44. Seattle: University of Washington Press.

Levinson, Stephen C. (2003). Space in language and cognition: Explorations in cognitive diversity. Cambridge: Cambridge University Press.

- \& David P. Wilkins (2006). Grammars of space. Cambridge: Cambridge University Press.

Mandler, Jean M., \& Nancy S. Johnson (1977). Remembrance of things parsed: Story structure and recall. Cognitive Psychology 9(1):111-51.

Moerman, Michael, \& Harvey Sacks (1988). On 'understanding' in the analysis of natural conversation. In Michael Moerman, Talking culture: Ethnography and conversation analysis, 180-86. (University of Pennsylvania publications in conduct and communication.) Philadelphia: University of Pennsylvania Press.

Propp, Vladímir (1928/1968). Morphology of the folktale. Austin: University of Texas Press.

Rossano, Federico (2012). Gaze behavior in face-to-face interaction. Nijmegen: Radboud University dissertation.

Rumelhart, David E. (1975). Notes on a schema for stories. In Daniel G. Bobrow \& Allan Collins (eds.), Representation and understanding: Studies in cognitive science, 211-36. New York: Academic Press.

Sacks, Harvey (1974). An analysis of the course of a joke's telling in conversation. In Richard Bauman \& Joel Sherzer (eds.), Explorations in the ethnography of speaking, 337-53. Cambridge: Cambridge University Press.

(1986). Some considerations of a story told in ordinary conversations. Poetics 15(1-2):127-38. (1992a). Lectures on conversation, vol. 1. Ed. by Gail Jefferson. Cambridge: Blackwell. (1992b). Lectures on conversation, vol. 2. Ed. by Gail Jefferson. Cambridge: Blackwell. , \& Emanuel A. Schegloff (1979). Two preferences in the organization of reference to persons in conversation and their interaction. In George Psathas (ed.), Everyday language: Studies in ethnomethodology, 15-21. New York: Irvington.

_ - Gail Jefferson (1974). A simplest systematics for the organization of turn-taking for conversation. Language 50(4):696-735.

Schegloff, Emanuel A. (1972). Notes on a conversational practice: Formulating place. In David N. Sudnow (ed.), Studies in social interaction, 75-119. New York: MacMillan/The Free Press. (1982). Discourse as interactional achievement: Some uses of 'uh huh' and other things that come between sentences. In Deborah Tannen (ed.), Analyzing discourse: Text and talk, 71-93. Washington, DC: Georgetown University Press.

- (1997). 'Narrative analysis' thirty years later. Journal of Narrative and Life History 7(1-4):97-106.

Sidnell, Jack (2000). Primus inter pares: Storytelling and male peer groups in an Indo-Guyanese rumshop. American Ethnologist 27(1):72-99.

(ed.) (2009). Conversation analysis: Comparative perspectives. Cambridge: Cambridge University Press.

(2010). Conversation analysis: An introduction. Chichester: Wiley-Blackwell.

Stivers, Tanya (2008). Stance, alignment, and affiliation during storytelling: When nodding is a token of affiliation. Research on Language \& Social Interaction 41(1):31-57.

_ ; N. J. Enfield: Penelope Brown; Christina Englert; Makoto Hayashi; Trine Heinemann; Gertie Hoymann; Federico Rossano; Jan Peter de Ruiter; Kyung-Eun Yoon; \& Stephen C. Levinson (2009). Universals and cultural variation in turn-taking in conversation. Proceedings of the National Academy of Sciences 106(26):10587-92. 
Thorndyke, Perry W. (1977). Cognitive structures in comprehension and memory of narrative discourse. Cognitive Psychology 9(1):77-110.

Wittenburg, Peter; Hennie Brugman; Albert Russel; Alex Klassmann; \& Han Sloetjes (2006). ELAN: A professional framework for multimodality research. In Proceedings of the 5th International Conference on Language Resources and Evaluation (LREC 2006), 1556-59. Online: http://tla.mpi.nl/tools/ tla-tools/elan/.

Yasui, Eiko (2011). Negotiating story entry: A micro-analytic study of storytelling projection in English and Japanese. Austin: University of Texas dissertation.

Zimmerman, Don H. (1999). Horizontal and vertical comparative research in language and social interaction. Research on Language \& Social Interaction 32(1-2):195-203.

(Received 10 May 2016; revision received 24 September 2016; accepted 30 October 2016; final revision received 31 October 2016)

Address for correspondence:

Mark Dingemanse

P.O. Box 3106500 AH Nijmegen,

The Netherlands mark.dingemanse@mpi.nl 